\title{
Impact of specific emergency measures on survival of out of hospital traumatic cardiac arrest: data from the northern french alps cardiac arrest registry.
}

\section{Dominique Savary ( $\sim$ dsavary74@gmail.com )}

CHU Angers: Centre Hospitalier Universitaire d'Angers https://orcid.org/0000-0001-8480-5348

\section{François Morin}

CHU Angers: Centre Hospitalier Universitaire d'Angers

\section{Delphine Douillet}

CHU Angers: Centre Hospitalier Universitaire d'Angers

\section{Thierry Roupioz}

Emergency Department, General Hospital, Annecy, France

\section{François Xavier Ageron}

Emergency Department, CHUV

\section{Adrien Drouet}

Emergency Department, General Hospital, Annecy, France

\section{Romain Charvet}

CHU Angers: Centre Hospitalier Universitaire d'Angers

\section{Bruno Carneiro}

CHU Angers: Centre Hospitalier Universitaire d'Angers

\section{Pierre Metton}

Northern French Alp Emergency Network, General hospital, Annecy

\section{Marc Fadel}

UNIV Angers, CHU Angers, Univ Rennes, Inserm, EHESP, Irset

\section{Alexis Descatha}

UNIV Angers, CHU Angers, Univ Rennes, Inserm, EHESP, Irset

\section{Original research}

Keywords: Advanced Life Support, Trauma, Cardiac Arrest

Posted Date: November 19th, 2020

DOI: https://doi.org/10.21203/rs.3.rs-110400/v1 
License: (c) (i) This work is licensed under a Creative Commons Attribution 4.0 International License. Read Full License 


\section{Abstract}

The management of Out of hospital Traumatic Cardiac Arrest (TCA) for professional rescuers combines advanced life support with specifics actions to treat potential reversible causes of the arrest: hypovolemia, hypoxemia, Tension Pneumothorax (TPx) and tamponade. The aim of this study was to assess the impact of specific rescue gestures on short-term outcomes in the context of resuscitation of patients with a pre-hospital TCA.

Methods: We conducted a retrospective study of all TCA treated in two emergency medical units (EM unit), which are part of the Northern Alps emergency network, from January 2004 to December 2017. Utstein variables and specific rescue actions in TCA were compiled: advanced airway management, fluid administration, pelvic stabilization or tourniquet application, bilateral thoracostomy, and thoracotomy procedures. The primary end point was the survival rate at day 30 with good neurologic outcome (cerebral performance category [CPC] score $1 \& 2$ ).

Results: 287 resuscitations attempt in TCA were included and 279 specific interventions were Identified: 262 Fluid expansion, 41 External Pelvic stabilizations, 5 tourniquets, 175 bilateral thoracostomies, (including 44 with TPx).

Conclusion: Among standard resuscitation measures to treat reversible causes of cardiac arrest, we were able to show that bilateral thoracostomy and tourniquet application on a limb hemorrhage improves survival of TCA. A larger sample for pelvic stabilization is necessary.

\section{Introduction}

Traumatic cardiac arrest (TCA) is associated with a poor outcome. The management of TCA patients has moved in the last decade from withholding treatment on the basis of futility $(1,2)$ to actively identifying and treating the cause of the arrest. After prioritizing basic and, if available, advanced life support, management for TCA should focus on the potentially reversible causes.

In the particular context of trauma, these potentially reversible causes are considered to be hypovolemia, hypoxemia, Tension Pneumothorax (TPx) and tamponade (3). The development of algorithms for the management of TCA have focused on the interventions specifically aimed at treating the pathology underlying these causes.

The Northern French Alps Emergency Network (RENAU) proposed in 2008 a consensus for the management of TCA (Additional file 1). The RENAU also has a cardiac arrest registry which also collects TCA. The aim of this study was to assess the impact of specific rescue gestures on short-term outcomes in the context of resuscitation of patients with a pre-hospital TCA treated by Emergency Medical Services (EMS).

\section{Method}


We conducted a retrospective study of all the TCA admitted in two emergencies medical units' part of the Northern French Alps Emergency Network (Emergency medical units of Annecy and St Julien) from January 2004 to December 2017.

\section{Data collection}

The RENAU comprises all hospitals and EMS systems of three mountainous counties (Isère, Savoie and Haute-Savoie), including 13 Mobile Emergency and Resuscitation Services. The cardiac arrest registry of RENAU is an exhaustive (4) register in accordance to Utstein Style previously described by Ageron et al (5). Since the first of January 2004, each case of OHCA has been recorded in electronic form completed by the emergency physician in charge of the patient and the dispatch center. During the study period, 23,772 cardiac arrests were reported in the RENAU registry, including $14 \%$ TCA.

To be able to describe extensively the TCA management, we restricted the sample to two emergency medical units (Annecy and St Julien) that have collected prehospital specific rescue actions in TCA.

\section{Variables}

Utstein relevant variables such as age (continuous), sex (male or female), presence of a witness (yes or no), bystanders present (yes or no), bystander CPR (yes or no), location of OHCA (home or not), first choc rhythm (choc rhythm or not), and intervention times were included.

Specific rescue actions in TCA were also collected: advanced airway management, fluid administration (expansion > $250 \mathrm{~mL}$ or not), pelvic stabilization or tourniquet application (yes or no), bilateral thoracostomy (realized or not) and results in three categories: not performed, performed but no TPx, performed and TPx, as well as thoracotomy procedures.

\section{Outcomes}

The patient's status (alive/dead) and its neurologic outcome (using standardized cerebral performance category [CPC] score) were obtained at day 30 from the receiving unit or phone follow-up interviews with research associates if the hospital discharge was obtained. The primary end point was the survival rate at day 30 with good neurologic outcome (CPC 1 \& 2). Secondary endpoints were the rate of patients admitted alive at the hospital and the rate of patients discharged alive from hospital.

\section{Statistical analyses}

Continuous variables are described using mean and standard deviations values. Categorical variables are described as proportions. For primary and secondary endpoints, logistic regressions were performed to assess differences of TCA managements. Crude and adjusted odds ratios (OR) with their $95 \%$ confidence intervals $(95 \% \mathrm{Cl})$ using relevant variables, including TCA treatment, were estimated. The sample size is predetermined due to study design. A p-value $<0.05$ was considered statistically significant. Sensitivity analyses using multiple imputations were planned using Multiple Imputation by Chained Equations (MICE, 20 imputations). Statistical analyses were all performed using SAS (Statistical Analysis Software, v 9.4 SAS inc., NC, Cary, USA), except multiple imputation with STATA software use (version 16.0; Stata 
Corp, College Station, TX, USA). The study complied with the Declaration of Helsinki and was approved by the ethics committee of the University Hospital of Clermont-Ferrand, Clermont-Ferrand, France (IRB no. $5891)$.

\section{Results}

\section{Overall results}

In the 13 years study period, a total of $3,856 \mathrm{OCHA}$ cases were attended to by emergency medical units. Of those, 1,954 patients underwent advanced life support and there 287 patients with TCA. Mean age was 46.8 year. ( $S D \pm 20.4$ ), ranging from 20 to 98 year. 285 of these patients $(99.3 \%)$ were in cardiac arrest when the EMS personnel arrived at the scene. In 172 (59.9\%) cases, bystanders were presents at the time of the event and in $79(27.5 \%)$ cases, bystanders began the gestures of resuscitation without delay (Table 1). The initially monitored heart rhythm was pulseless electric activity in $9 \%$ of the cases $(n=$ $22)$, asystole in $79.4 \%(n=228)$, fibrillation in $7.7 \%(n=22)$ and ventricular tachycardia in one $(0,35 \%)$ case. Mean EM Unit-time was $12.1 \pm 7.8 \mathrm{~min}$.

Table 1

Patients description with characteristic among admitted hospital alive characteristics and he 30 days survival with good neurological prognosis (cerebral performance category [CPC] score 1 \& 2)

\begin{tabular}{|c|c|c|c|c|c|}
\hline & \multicolumn{3}{|c|}{ Admitted alive at hopsital } & \multicolumn{2}{|c|}{$\begin{array}{l}30 \text { days survival with good neurological } \\
\text { prognosis }\end{array}$} \\
\hline & $\mathrm{N}$ & $\begin{array}{l}\text { Nof case } \\
\text { admitted } \\
\text { alive at } \\
\text { hospital }\end{array}$ & $\begin{array}{l}\text { Proportion } \\
\text { (\%) of } \\
\text { admitted alive } \\
\text { at hospital }\end{array}$ & $\begin{array}{l}\mathrm{N} \text { of case } 30 \text { days } \\
\text { survival with good } \\
\text { neurological } \\
\text { prognosis }\end{array}$ & $\begin{array}{l}\text { Proportion (\%) of } 30 \\
\text { days survival with good } \\
\text { neurological prognosis }\end{array}$ \\
\hline $\begin{array}{l}\text { Male, } n \\
(\%)\end{array}$ & 232 & 45 & 19.40 & 6 & 2.59 \\
\hline $\begin{array}{l}\text { Bystander } \\
\text { witnessed, } \\
\mathrm{n}(\%)\end{array}$ & 172 & 30 & 17.44 & 3 & 1.74 \\
\hline $\begin{array}{l}\text { First choc } \\
\text { rhythm, n } \\
(\%)\end{array}$ & 22 & 7 & 31.82 & 3 & 13.64 \\
\hline $\begin{array}{l}\text { Bystander } \\
\text { CPR, n (\%) }\end{array}$ & 79 & 15 & 18.99 & 1 & 1.27 \\
\hline $\begin{array}{l}\text { Location } \\
\text { at home, n } \\
\text { (\%) }\end{array}$ & 42 & 11 & 26.19 & 3 & 7.14 \\
\hline \multicolumn{6}{|c|}{ CPR: Cardio Pulmonary Resuscitation } \\
\hline \multicolumn{6}{|c|}{ Bold $\mathrm{P}<0.05$} \\
\hline
\end{tabular}


Endo Tracheal Intubation (ETI) failure represents 7 cases out of 296 (2.4\%). If advanced airway support cannot be provided then basic airway support using airway adjuncts and bag valve mask ventilation was performed.

Prehospital specific rescue actions were identified in 279 cases (Fig. 1). During the study period, no transfusion in the setting and no thoracotomy were performed.

\section{Outcome}

There were 57 (19.9\%) patients admitted alive at hospital. Favorable functional survival (CPC 1 \& 2 ) at day 30 days was observed for $8(2.8 \%)$ out of 287 patients. Primary and secondary outcomes for each prehospital specific rescue action are presented in the figure (Table 2). Thoracostomy was performed in $175(61.0 \%)$ cases, pelvic stabilization in $41(14.3 \%)$ cases, tourniquet application in $5(1.4 \%)$ cases whereas fluid expansion in 262 (91.3\%). Though number of subjects were low, bilateral thoracostomy in case of pneumothorax and tourniquet application were associated with the main outcome.

Thoracostomy performed without pneumothorax showed no association with a good or a bad prognosis. Similar results were observed using MICE (Table 2). 
Table 2

Trauma specific measures and characteristics according to the admission alive to hospital and 30 days survival with good neurological prognosis (CPC 1\&2)

\section{Admitted alive at hospital}

\begin{tabular}{|c|c|c|c|c|c|}
\hline & Total & $\begin{array}{l}\text { Number } \\
\text { of } \\
\text { cases }\end{array}$ & $\begin{array}{l}\text { Proportion } \\
\text { (\%) ad }\end{array}$ & $\begin{array}{l}\text { Crude Odds Ratios } \\
\text { (95\% confidence } \\
\text { interval) }\end{array}$ & $\begin{array}{l}\text { Adjusted Odds Ratios } \\
{[95 \% \text { confidence }} \\
\text { interval) * }\end{array}$ \\
\hline $\begin{array}{l}\text { Fluid } \\
\text { Expansion, } \mathrm{n} \\
(\%)\end{array}$ & 262 & 52 & 19,85 & $0.99[0.36 ; 2.76]$ & $0.80[0.28 ; 2.35]$ \\
\hline \multirow{2}{*}{$\begin{array}{l}\text { Bilatéral } \\
\text { Thoracostomy, } \\
\mathrm{n}(\%)\end{array}$} & 175 & 40 & 22,86 & $1.64[0.88 ; 3.06]$ & $1.62[0.85 ; 3.07]$ \\
\hline & 44 & 22 & 50 & $5.59[2.55 ; 12.25]$ & $5.81[2.55 ; 13.24]$ \\
\hline $\begin{array}{l}\text { - With TPx, n } \\
(\%)\end{array}$ & 131 & 18 & 13,74 & $0.89[0.43 ; 1.82]$ & $0.84[0.40 ; 1.77]$ \\
\hline \multicolumn{6}{|l|}{$\begin{array}{l}\text { - Without TPx, } \\
\text { n (\%) }\end{array}$} \\
\hline $\begin{array}{l}\text { Tourniquet, } \mathrm{n} \\
\text { (\%) }\end{array}$ & 5 & 2 & 40 & $2.75[0.45 ; 16.87]$ & $5.37[0.67 ; 43.11]$ \\
\hline $\begin{array}{l}\text { Stabilization } \\
\text { Pelvis, n (\%) }\end{array}$ & 41 & 11 & 26,83 & $1.59[0.74 ; 3.41]$ & $1.80[0.80 ; 4.02]$ \\
\hline & & \multicolumn{4}{|c|}{30 days survival wit good neurological prognosis } \\
\hline & Total & $\begin{array}{l}\text { Number } \\
\text { of } \\
\text { cases }\end{array}$ & $\begin{array}{l}\text { Proportion } \\
(\%)\end{array}$ & $\begin{array}{l}\text { Crude Odds Ratios } \\
\text { ( } 95 \% \text { confidence } \\
\text { interval) }\end{array}$ & $\begin{array}{l}\text { Adjusted Odds Ratios } \\
{[95 \% \text { confidence }} \\
\text { interval) * }\end{array}$ \\
\hline $\begin{array}{l}\text { Fluid } \\
\text { Expansion, } \mathrm{n} \\
(\%)\end{array}$ & 262 & 7 & 2,67 & $0.66[0.08 ; 5.58]$ & $0.39[0.04 ; 4.01]$ \\
\hline \multirow{2}{*}{$\begin{array}{l}\text { Bilatéral } \\
\text { Thoracostomy, } \\
\text { n (\%) }\end{array}$} & 175 & 7 & 4 & $4.58[0.56 ; 37.77]$ & $6.14[0.62 ; 60.88]$ \\
\hline & 44 & 5 & 11,36 & $14.23[1.61 ; 125.61]$ & $36.63[2.46 ; 546.35]$ \\
\hline $\begin{array}{l}\text { - With TPx, n } \\
(\%)\end{array}$ & 131 & 2 & 1,53 & $1.72[0.15 ; 19.23]$ & 1.17 [ 0.06; 24.09] \\
\hline \multicolumn{6}{|l|}{$\begin{array}{l}\text { - Without TPx, } \\
\text { n (\%) }\end{array}$} \\
\hline $\begin{array}{l}\text { Tourniquet, } \mathrm{n} \\
(\%)\end{array}$ & 5 & 2 & 40 & $30.67[4.30 ; 218.48]$ & $89.11[5.23 ; 1516.86]$ \\
\hline
\end{tabular}

TPx: Tensio Pneumothorax

* adjusted on age, sex, first choc rhythm, Bystander cardiopulmonary resuscitation location at home, and delay to CPR, each parameter in one model separate. Bold $\mathrm{P}<0.05$ 


\section{Admitted alive at hospital}

$\begin{array}{llllll}\text { Stabilization } & 41 & 3 & 7,42 & 3.81[0.87 ; 16.58] & 4.87[0.89 ; 26.68]\end{array}$

Pelvis, $\mathrm{n}(\%)$

TPx: Tensio Pneumothorax

* adjusted on age, sex, first choc rhythm, Bystander cardiopulmonary resuscitation location at home, and delay to $\mathrm{CPR}$, each parameter in one model separate. Bold $\mathrm{P}<0.05$

\section{Discussion}

To our knowledge, this is the first study describing the outcome of each trauma-specific additive measures performed at the event site, in addition to standard resuscitation measures to treat reversible causes of cardiac arrest. These results highlight that for each action analyzed in separation (thoracostomy, pelvic stabilization in patients suspected of pelvic fractures or tourniquet application on a limb hemorrhage) improves survival independently from fluid expansion. The global results indicate that $19.9 \%$ of TCA were admitted alive at hospital, almost $2.7 \%$ survived at day 30 , and when patients survived it was with favorable functional outcome (CPC $1 \& 2$ ). The lower survival rate, compared to other cohorts could be due too geographical conditions of intervention and the fact almost all patients were in cardiac arrest at the time of treatment. Our study was conducted in a specific area with a very low rate of penetrating trauma $(7.6 \%)$ and a remarkable rate of TCA from rural or mountain activities (18\%), with often difficult and prolonged prehospital care (6).

\section{Hypoxemia}

The recommendations specify that definitive airway management with a tracheal tube should be achieved at the earliest opportunity if the healthcare provider is adequately trained in this intervention. In the present trial, the airway management was performed by trained emergency physicians in accordance with international recommendations (7). The difficult intubation rate in the out of hospital setting wasn't researched but the incidence of ETI failure was low (2.6\%) and comparable with a recent European study (8). There are many causes of asphyxial cardiac arrest, but in the context of TCA, it is mainly due to airway obstruction and traumatic asphyxia. This represents $13 \%$ of the cause of traumatic cardiac arrest (9). We hypothesized that the high rate of ETI increased oxygenation in our cohort.

Bilateral thoracostomy is part of the wider resuscitation effort which includes intubation and ventilation to increase oxygenation (10). Our network considered bilateral pleural decompression as an essential measure to eliminate the reversible causes of cardiovascular arrest associated with trauma. Identifying patients with a TPx using only information from a mechanism of injury or a physical examination can be challenging in cardiac arrest patient. Incorporating ultrasound examinations into prehospital decisionmaking for patients with TCA may facilitate the early identification of treatable causes (11). This requires 
equipping emergency teams with portable ultrasound and having emergency physicians with extensive ultrasonographic experience (12). Such practice remains controversial in particular because it is time consuming $(13,14)$. Taking into account that bilateral thoracostomy was found useful in case of pneumothorax and was not related to a poor prognosis, this intervention should be more widely done (15). However, we observed that bilateral thoracostomy was only carried out in only $61 \%$ of cases. This rate corresponds to that observed by Mistry with a doctor presence among the air ambulance crew (15). But this confirms the conclusions of previous publications which claimed that implementation was too rare $(16,17)$. The proportion of TPx in our arrest group was $15.3 \%(44 / 287)$, which is slightly higher than in the Berlin cohort (13\%) (9). The outcomes for patients with TPx who underwent on-scene thoracostomy were good in our group: eight patients have survived the first hours and five survived to hospital discharge. Other publications showed that this active management is more effective and improves survival. In view of our results, it appears that performing a bilateral thoracostomy doesn't worsen the patient's prognosis even if it does not reveal a TPX.

\section{Hypovolemia}

TCA caused by major hemorrhage has a very poor prognosis (18). The majority of patients in our cohort have benefited from a re-expansion of at least $250 \mathrm{~mL}$ isotonic saline. Regardless of the success of the expansion, this intervention showed no survival improvement. This result is consistent with other studies $(18,19)$. In profound hypovolemia, chest compressions are likely to be ineffective due to poor cardiac filling (20) but it is currently recommended $(21,22)$. A study on dogs have demonstrated that chest compressions do not improve survival in hypovolemic cardiac arrest (23). Moreover, immediate diagnosis of severe hypovolemia may be difficult in prehospital setting. In our study, there were no pre-hospital red blood cells transfusion. While different teams have shown an improvement in the rate of return of spontaneous circulation following TCA, a survival benefit has not been demonstrated (24).

Although fluid re-expansion wasn't operative, pelvic stabilization and tourniquet application were significantly effective on survival. First, in mountainous area, many cardiac arrests related to falls $(6,25)$ and these mechanisms regularly cause long bone and pelvic fractures as well as limb hemorrhages. In a recent German study, the authors concluded that more emphasis should be placed on temporary provisional external pelvic stabilization in TCA which was performed too rarely even though an instable pelvic ring was apparent during the postmortem external examination (26). However, $12 \%$ of patients in this study had received external stabilization of the pelvis which is a much larger figure than ours. We can imagine that this action could have been proposed in several other cases. Second the use of emergency trauma pressure dressings, and tourniquets was successfully proposed for battlefield settings (27). Delayed application of a tourniquet was associated with more negative outcomes in several studies. Therefore, the role of the dispatch center is essential for accompanying bystanders to perform these essential actions early.

\section{Cardiac Tamponade}


The definitive treatment for traumatic cardiac tamponade causing a cardiac arrest is a resuscitative emergency thoracotomy. Most cases of cardiac tamponade are secondary to penetrating trauma which are rarely described in France and in our area (6). This is in contrast to the United States, where penetrating trauma may represent up to $30 \%$ of trauma patients and $45 \%$ of cardiac arrest patients (28); However cardiac injury has been described for up to $20 \%$ of patients involved in road traffic collisions (29), and this pathology should be considered in patients with significant blunt chest trauma. But this measure is effective if it is carried out within a short timeframe (7), which is not possible in our geographic area, although helicopter transport and sometimes mechanical chest compression device have proved effective in reducing time to admission (30). In different European countries, prehospital thoracotomy may be a possibility (31). In France, currently this technique is available only in big cities such as Paris, Lyon or Lille.

Our study has several limitations. First, it was conducted in a specific population and area with few penetrating traumas and a high number of mountain-related injuries. In many centers in France, the number of severe traumas is significantly lower because of a decrease in motor vehicle accidents, whereas TCA prevalence in our area remains steady. Thus, our results cannot be a perfect reflection of the reality in France and Europe. Second, since this was a retrospective observational study, it may have been subject to selection bias relating to survival. In addition, TCA victims regularly have multiple injuries resulting in critical hypoxemia, TPx or severe hypovolemia, and our study only measures the effects of each actions separately. More over the number event per variable is low that results in a lack of power of the multivariate model. Finally, the RENAU cardiac arrest registry is not totally exhaustive (only $81.8 \%$ of data was complete). While a rate higher than $75 \%$ is acceptable for a prospective registry, we are still missing some data for a number of CA patients $(6,32)$.

\section{Conclusion}

Among standard resuscitation measures to treat reversible causes of cardiac arrest, we were able to show that systematic bilateral thoracostomy and tourniquet application on a limb hemorrhage improves survival of TCA. Larger sample for pelvic stabilization is necessary. It would also be interesting to detail guidelines and recommendations implementation that are always questionable on their application.

\section{Abbreviations}

CPC: Cerebral Performance Category

EMS: Emergency Medical Services

ETI: Endo Tracheal Intubation

MICE: Multiple Imputation by Chained Equations

OR: Odds Ratio

Page 10/15 
RENAU: Northern French Alps Emergency Network

SAS: Statistical Analysis Software

TCA: Traumatic Cardiac Arrest

TPx: Tensio Pneumothorax

\section{Declarations}

\section{Ethics approval and consent to participate:}

The study complied with the Declaration of Helsinki and was approved by the ethics committee of the University Hospital of Clermont-Ferrand, Clermont-Ferrand, France (IRB no. 5891).

Consent for publication:

Not Applicable

\section{Availability of data and material:}

Please contact author for data requests

\section{Competing interests:}

The authors declare that they have no competing interests.

\section{Funding:}

This study did not receive any grant or financial support.

\section{Authors' contributions:}

All authors have made substantial contributions to the conception and design of the study. DS and AD contributed to the study conception and design, and performed the initial data analysis. DS, FM and DD prepared the first draft of the manuscript; all authors gave their final approval of the version to be submitted. The manuscript has not been published previously and is not under consideration elsewhere. The study was performed in CHU Angers, ANGERS, FRANCE and CH Annecy Genevois, ANNECY, FRANCE.

\section{Acknowledgements:}

The authors acknowledge their gratitude to Sabrina Pitet for help in structuring tables.

\section{References}


1- Hopson LR, Hirsh E, Delgado J, Domeier RM, Krohmer J, McSwain NE Jr, et al. Guidelines for Withholding or Termination of Resuscitation in Prehospital Traumatic Cardiopulmonary Arrest. J Am Coll Surg 2003; 196(3), 475-481.

2- Rosemurgy AS, Norris PA, Olson SM, Hurst JM, Albrink MH. Prehospital traumatic cardiac arrest: the cost of futility. J Trauma 1993;35(3):468-73.

3- Lockey DJ, Lyon RM, Davies GE. Development of a simple algorithm to guide the effective management of traumatic cardiac arrest. Resuscitation 2013; 84(6), 738-742.

4- Savary D, Ricard C, Drouet A, Gaillard A, Geri G, Fadel M, et al. How exhaustive are out of hospital cardiac arrest registers? The example of the Northern French Alps Cardiac Arrest Registry. Resuscitation 2020.1;148:57-58.

5- Ageron FX, Debaty G, Gayet-Ageron A, Belle L, Gaillard A, Monnet MF et al. Impact of an emergency medical dispatch system on survival from out-of-hospital cardiac arrest: a population-based study. Scand J Trauma Resusc Emerg Med. 2016; 24:53.

6- Faucher A, Savary D, Jund J, Carpentier F, Payen JF, Danel V. Optimize the resuscitation of prehospital cardiac arrest in trauma patients: a prospective register"s experience. Ann Fr Anesth Reanim 2009; 28(5):442-7- Soar J, Nolan JP, Böttiger BW, et al. European Resuscitation Council Guidelines for Resuscitation 2015. Resuscitation 2015; 95, 100-147.

8- Jabre P, Penaloza A, Pinero D, Duchateau FX, Borron SW, Javaudin F et al. Effect of Bag-Mask Ventilation vs Endotracheal Intubation During Cardiopulmonary Resuscitation on Neurological Outcome After Out-of-Hospital Cardiorespiratory Arrest. JAMA 2018; 319(8), 779.

9- Kleber C, Giesecke MT, Lindner T, Haas NP, Buschmann CT. Requirement for a structured algorithm in cardiac arrest following major trauma: Epidemiology, management errors, and preventability of traumatic deaths in Berlin. Resuscitation 2014; 85(3), 405-410.

10- Huber-Wagner S, Lefering R, Qvick M, Kay MV, Paffrath T, Mutschler W et al. Outcome in 757 severely injured patients with traumatic cardiorespiratory arrest. Resuscitation 2007;75(2):276-85.

11-Ketelaars R, Hoogerwerf N, Scheffer GJ. Prehospital Chest Ultrasound by a Dutch Helicopter Emergency Medical Service. J Emerg Med 2013; 44(4), 811-817.

12- Gardner KF, Clattenburg EJ, Wroe P, Singh A, Mantuani D, Nagdev A. The Cardiac Arrest Sonographic Assessment (CASA) exam - A standardized approach to the use of ultrasound in PEA. Am J Emerg Med 2018; 36(4), 729-731.

13- Long B, April MD, Koyfman A. Ultrasound Should Not be Routinely Used During Cardiopulmonary Resuscitation for Shockable Rhythms. Ann Emerg Med 2020; 75(4), 515-517. 
14- Huis in 't Veld MA, Allison MG, Bostick DS, Fisher KR, Goloubeva OG et al. Ultrasound use during cardiopulmonary resuscitation is associated with delays in chest compressions. Resuscitation 2017; 119, 95-98.

15- Mistry N, Bleetman A, Roberts KJ. Chest decompression during the resuscitation of patients in prehospital traumatic cardiac arrest. Emerg Med J 2009; 26(10), 738-740.

16- Buschmann C, Schulz T, Tsokos M, Kleber C. Emergency medicine techniques and the forensic autopsy. Forensic Sci Med Pathol 2012, 9(1), 48-67.

17- Kleber C, Giesecke MT, Tsokos M, Haas NP, Buschmann CT. Trauma-related Preventable Deaths in Berlin 2010: Need to Change Prehospital Management Strategies and Trauma Management Education. World J Surg 2013; 37(5), 1154-1161.

18- Lockey D, Crewdson K, Davies G. Traumatic cardiac arrest: who are the survivors? Ann Emerg Med $2006 ; 48: 240-4$.

19- Bickell WH, Wall Jr MJ, Pepe PE, Martin RR, Ginger VF, Allen MK et al. Immediate versus delayed Fluid resuscitation for hypotensive patients with penetrating torso injuries. N Engl J Med 1994; 331:1105-1109.

20- Luna GK, Pavlin EG, Kirkman T, Copass MK, Rice CL. Hemodynamic Effects of External Cardiac Massage in Trauma Shock. J Trauma 1989; 29(10), 1430-1433.

21- Revell M, Porter K, Greaves I. Fluid resuscitation in prehospital trauma care: a consensus view. Emerg Med J 2002; 19(6), 494-498.

22- National Clinical Guideline Centre (UK). Major Trauma: Assessment and Initial Management. London: National Institute for Health and Care Excellence (UK); 2016.

23- Jeffcoach DR, Gallegos JJ, Jesty SA, Coan NC, Chen J, Heidel ER et al. Use of CPR in hemorrhagic shock, a dog model. Journal of Trauma Acute Care Surg 2016; 81(1), 27-33.

24- Brown JB, Sperry JL, Fombona A, Billiar TR, Peitzman AB, Guyette FX. Pre-Trauma Center Red Blood Cell Transfusion Is Associated with Improved Early Outcomes in Air Medical Trauma Patients. J Am Coll Surg 2015; 220(5), 797-808.

25- Bouzat P, Broux C, Ageron FX, Gros I, Levrat A, Thouret JM et al. Impact de la mise en place d'un réseau de soins en traumatologie sur la mortalité des patients traumatisés graves du bassin. Ann $\mathrm{Fr}$ d'Anesth Reanim 2013; 32(12), 827-832.

26- Ondruschka B, Baier C, Dreßler J, Höch A, Bernhard M, Kleber C et al. Additional emergency medical measures in trauma-associated cardiac arrest. Anaesthesist 2017; 66(12), 924-935. 
27- Kragh JF, Littrel ML, Jones JA, Walters TJ, Baer DG, Wade CE et al. Battle Casualty Survival with Emergency Tourniquet Use to Stop Limb Bleeding. J Emerg Med 2011; 41(6), 590-597.

28- Hoyt DB, Shackford SR, Davis JW, Mackersie RC, Hollingsworth-Fridlund P. Thoracotomy During Trauma Resuscitations-An Appraisal by Board-certified General Surgeons. J Trauma 1989; 29(10), 1318-1321.

29- Fitzgerald M, Spencer J, Johnson F, Marasco S, Atkin C, Kossmann T. Definitive management of acute cardiac tamponade secondary to blunt trauma. Emerg Med Australas 2005; 17(5-6), 494-499.

30-Tazarourte K, Sapir D, Laborne FX, Briole N, Letarnec JY, Atchabahian A et al. Refractory cardiac arrest in a rural area: mechanical chest compression during helicopter transport Acta Anaesthesiol Scand. 2013 Jan;57(1):71-6.

31- Coats TJ, Keogh S, Clark H, Neal C. Prehospital Resuscitative Thoracotomy for Cardiac Arrest after Penetrating Trauma: Rationale and Case Series. J Trauma $2001 ;$ 50(4), 670-673.

32- Fourny M, Belle L, Labarère J Senee D, Savary D, Debaty G et al. Analysis of the accuracy of a coronary syndrome register. Arch Mal Coeur Vaiss 2006; 99(9):798-803.

\section{Figures}




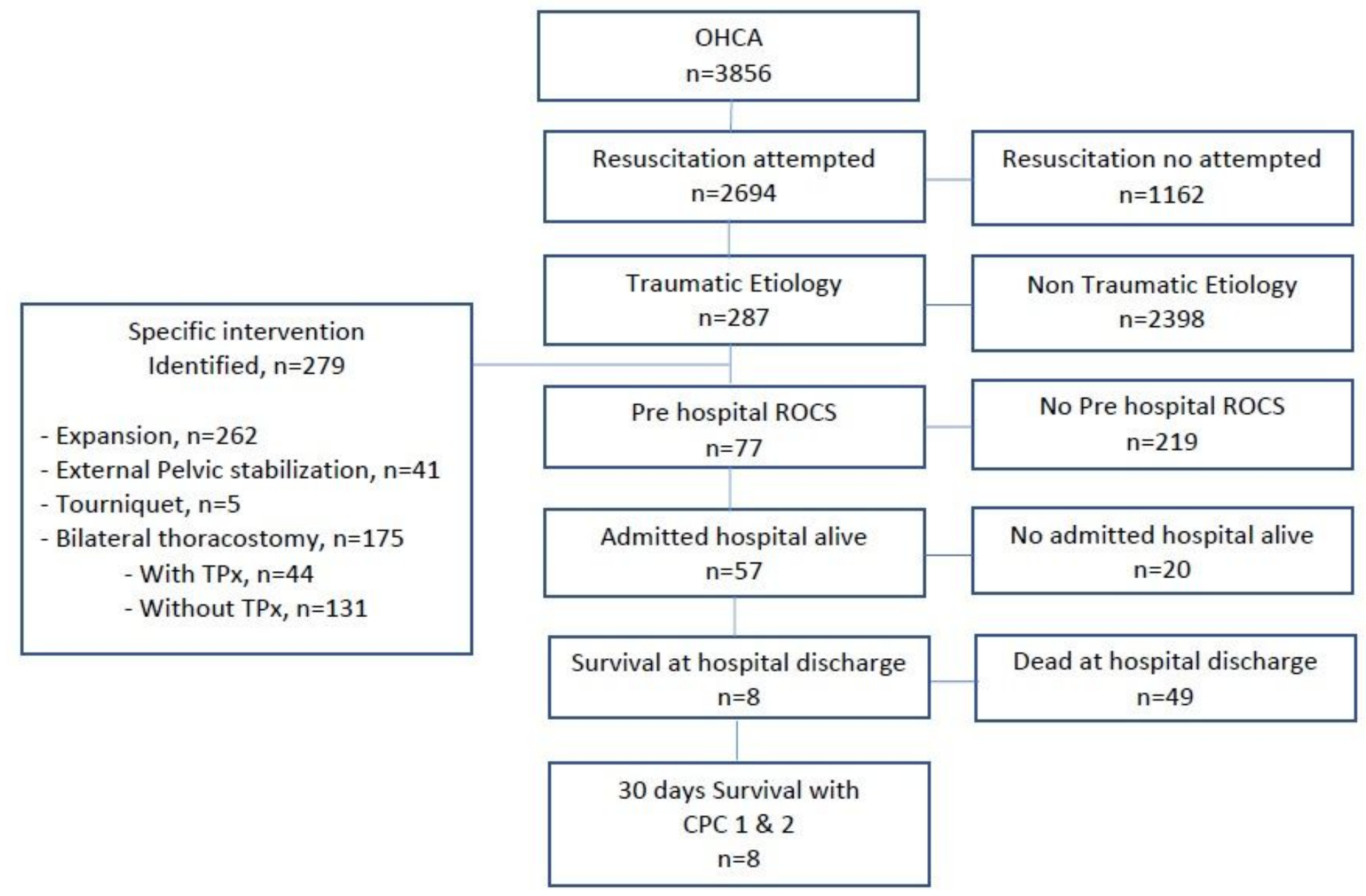

Figure 1

Flow chart of inclusion in the study

\section{Supplementary Files}

This is a list of supplementary files associated with this preprint. Click to download.

- AdditionalfileTCAspecificmeasures.docx 